JCE (Journal of Childhood Education)

Vol. 4 No. 2 Tahun 2020 | Hal. 103 - 125

2620-3278 (E-ISSN), 2598-2184 (P-ISSN)

\title{
KEPRIBADIAN ANAK DARI POLA ASUH AUTHORITARIAN DALAM PRESPEKTIF ISLAM
}

Siti Makhmudah ${ }^{1}$

STAIM nglawak Kertosono Nganjuk, Indonesia makhmudahsiti87@gmail.com

\begin{tabular}{l}
\hline Informasi artikel \\
\hline Received: \\
August 13, 2020. \\
Revised: \\
August 26, 2020. \\
Publish: \\
September 09, 2020. \\
\\
Kata kunci: \\
Kepribadian anak, \\
Pola asuh \\
authoritarian, \\
Perspektif Islam
\end{tabular}

Keywords:

Child's Personality;

Parenting and

Authoritarian

\begin{abstract}
ABSTRAK
Masalah anak-anak dan pendidikan adalah suatu persoalan yang amat menarik bagi seorang pendidik dan orang tua yang setiap saat menghadapi anak-anak yang membutuhkan pendidikan. Mengasuh dan membesarkan anak berarti memelihara kehidupan dan kesehatannya serta mendidiknya dengan penuh ketulusan dan kasih sayang juga selalu memaafkan kesalahan anak. Berangkat dari alasan mendasar ini peneliti tertarik untuk membahas lebih lanjut terkait masalah ini dengan harapan semoga bisa memberikan pengembangan pendidikan kedepannya. Penelitian ini bertujuan untuk mengetahui bagaimana kepribadian anak dari pola asuh ibu yang authoritarian. Metode penelitian ini dg menggunakan deskriptif kualitatif pendekatan studi kasus. Subyek penelitian ini adalah seorang anak perempuan berumur 10 tahun yang duduk di bangku sekolah dasar. Hasil penelitian menunjukkan bahwa pola asuh ibu yang authoritarian berpengaruh besar terhadap pembentukan kepribadian anak, anak semakin berani, mudah berontak dan mudah terpengaruh, mesti disisi lain anak dapat disiplin dan belajar menghargai waktu. Subyek penelitian ini adalah seorang anak perempuan berumur 10 tahun yang duduk di bangku sekolah dasar. Tujuan penulisan ini untuk mengetahui dan membahas peranan keluarga sesuai presfpektif pendidikan agama Islam untuk menutupi dampak orang tua menerapkan pola asuh yang authoritarian.
\end{abstract}

ABSTRACT

The problem of children and education is a very interesting problem for an educator and parents who face children who need education all the time. Nurturing and raising a child means caring for his life and health and educating him with full sincerity and affection also also forgive the mistakes of children. Departing from this fundamental reason researchers are interested in discussing further related to this issue in the hope that it can provide educational development going forward. This study aims to determine how the child's personality from authoritarian parenting. This research method uses descriptive qualitative case study approach. The subject of this study was a 10-year-old girl who was in elementary school. The results showed that the authoritarian parenting mother had a great influence on the formation of the child's personality, the child became bolder, easily rebelled and easily influenced, the child must be on the other hand to be disciplined and learn to respect time. The subject of this study was a 10-year-old girl who was in elementary school. 
This work is licensed under a Creative Commons Attribution-ShareAlike 4.0 International License.

\section{PENDAHULUAN}

Pada saat ini banyak penelitian tentang judul masalah anak dan pendidikan. Sebagai contoh "Pendidikan Anak Usia Dini: Stimulasi \& Aspek Perkembangan Anak". Menjelaskan ragam stimulasi yang bisa diberikan untuk meningkatkan perkembangan anak dalam belajar. Penelitian ini bagus dalam hal penyusunan data ragam stimulus yang dipakai. Tetapi ada beberapa masalah yaitu hasil penelitian yang kurang begitu jelas dalam penjabarannya terkait pola pendidikan dalam keluarga terutama ibu yang menurut peneliti juga berpengaruh dalam proses perkembangan anak selain pemberian stimulasi disekolah yang tak kalah pentingnya. Dari permasalahan - permasalahan yang ada berdasarkan hasil penelitian peneliti diatas tadi bahwa di artikel ini peneliti akan memperkuatnya dengan pola pendidikan atau pola asuh di lingkungan keluarga terutama dari seorang ibu kepada anakany. Dan supaya tidak terlalu luas penjabrannnya dan bisa spesifik hasilnya maka subjek penelitian disini hanya kusus pada anak usia 10 tahun yaitu masa sesaat setelah anak terlepas dari usia golden age mereka.

Faktor terbesar yang membentuk kepribadian anak adalah lingkungan keluarga, terutama sikap Orangtua (A Chairan Marzuki, 1998). Sikap, perilaku dan kebiasaan orang tua selalu dilihat, dinilai, dan ditiru oleh anak dan kemudian menjadi kebiasaan pula bagi anak-anak mereka. Apapun stimulus yang diterima sangat berdampak pada perkembangan anak karena dari stimulus yang diterima, secara tidak disadari otak anak akan mengelola dan menyimpan sehingga menjadi sebuah ilmu pengetahuan. Oleh karena itu orang tua hendaknya memberikan stimulus yang tepat bagi anaknya, terutama dalam hal ini adalah seorang ibu. Ibu sangat berpengaruh besar dalam pembentukan watak anak (Mohammad Fauzhil Adhim, 1997).

Pengalaman pada masa kecil sang anak yang tumbuh dari suasana keluarga yang ia tempati (Ma'ruf Zurayk, 1983). Dalam keluarga, individu pertama kali belajar berinteraksi dengan orang lain. Pengalaman anak didalam keluarga memberikan kesan tertentu yang terus melekat, sekalipun tidak selamanya disadari oleh anak, dan kesan tersebut mewarnai perilaku yang terpancar dalam kehidupan sehari-hari. 
Masalah anak-anak dan pendidikan adalah suatu persoalan yang amat menarik bagi seorang pendidik dan orang tua yang setiap saat menghadapi anak-anak yang membutuhkan pendidikan. Proses pembentukan tingkah laku atau kepribadian pada anak hendaklah dimulai dari masa kanak-kanak, yang dimulai dari selesainya masa menyusui hingga anak berumur enam atau tujuh tahun. Masa ini termasuk masa yang sangat sensitif bagi perkembangan kemampuan berbahasa, cara berpikir, dan sosialisasi anak. Di dalamnya terjadilah proses pembentukan jiwa anak yang menjadi dasar keselamatan mental dan moralnya. Pada saat ini, orang tua harus memberikan perhatian ekstra terhadap masalah pendidikan anak dan mempersiapkannya untuk menjadi insan yang handal dan aktif di masyarakatnya. (Lestari, 2015) Mengasuh dan membesarkan anak berarti memelihara kehidupan dan kesehatannya serta mendidiknya dengan penuh ketulusan dan kasih sayang juga selalu memaafkan kesalahan anak. Firman Allah swt dalam QS.Ali 'Imran (3) ayat 134, yaitu "tidak mudah marah dan gemar memaafkan kekeliruan anak-anaknya”. Selain itu, dalam bergaul dengan anak-anaknya hendaknya orang tua (ayah dan ibu) berlaku kasih sayang. Karena sikap kasih sayang akan menumbuhkan kecintaan pada diri anak-anak terhadap kedua orang tuanya, bahkan Allah sendiri mencintai perilaku kasih sayang ini.

Secara umum tugas tanggung jawab mengasuh anak adalah tugas kedua orang tuanya dan kunci orang tua dapat menjalankan tanggung jawabnya secara baik dalam memimpin keluarga dan anaknya adalah keimanan kepada Allah, hari akhirat serta perilaku yang baik sebagai contoh bagi anaknya. Mengasuh anak adalah mendidik, membimbing, memelihara, mengurus makanan, minuman, pakaian, dan kebersihannya atau pada segala perkara yang seharusnya diperlukan oleh anak. Karena memang orang tua merupakan kuasa asuh bagi keluarga yakni kekuasaan orang tua untuk mengsuh, mendidik, memelihara, membina, melindungi, dan menumbuhkembangkan anak sesuai dengan agama yang di anutnya dan kemampuan, bakat, serta minatnya.

Peran sebuah keluarga yang harmonis dalam proses perkembangan manusia yang terdiri dari beberapa fase. Pada fase awal-fase anak-anak- peranan keluarga terutama orang tua dalam mengasuh anak cukup signifikan sebab keluarga merupakan 
agen sosialisasi primer. Keberhasilan dalam mengasuh salah satunya ditentukan oleh pola asuh. Dengan demikian tulisan ini mencoba mengulas mengenai pola asuh yang sesuai untuk membentuk karakter positif pada anak. Pola pengasuhan seharusnya memang diperhatikan oleh orang tua secara serius karena menentukan kepribadian atau karakter anak. Hasilnya secara teoritik ada tiga jenis pola asuh, yaitu otoriter, permisif, dan demokratis. Pola otoriter cenderung koersif dan rigid sehingga kadang justru membuat anak menjadi tertekan. Sedangkan pola permisif cenderung menjadikan anak menjadi sosok yang egois dan tidak peka karena orang tua cenderung memenuhi kebutuhan materiil. Pola asuh ideal adalah demokratis karena pola komunikasi dua arah sehingga menempatkan anak pada posisi bebas namun tetap terkontrol.(Rakhmawati, 2015).

Memang, beban tanggung jawab orang tua yang amat berat ini merupakan tantangan bagi manusia yang telah berubah menjadi orang tua. Mereka juga harus mendidik dan mengarahkan anak pada perbuatan yang seharusnya dilakukan, dan menjelaskan boleh atau tidaknya perbuatan itu dilakukan oleh anak, agar anak mengerti ketidaklarangan yang diterapkan orang tua terhadapnya (Hasan, 2011:69). Mendidik anak dengan baik dan benar berarti menumbuh kembangkan totalitas potensi anak secara wajar. Potensi jasmaniah dan rohaniah anak diupayakan tumbuh dan berkembang secara selaras. Potensi jasmaniah anak diupayakan pertumbuhannya secara wajar melalui kebutuhan-kebutuhan jasmani, seperti pemenuhan kebutuhan sandang, pangan, dan papan. Sedangkan potensi rohaniah anak diupayakan pengembangannya secara wajar melalui usaha pembinaan intelektual, perasaan, dan budi pekerti. Karena hak anak adalah bagian dari hak asasi manusia yang wajib dijamin, dilindungi, dan dipenuhi oleh orang tua, keluarga, masyarakat, pemerintah, dan negara.

Melindungi anak bukan berarti selalu melarang anak akan tetapi melindungi anak adalah menjaga anak dari ha-hal yang membahayakan dirinya. Akan tetapi orang tua yang terlalu sering melarang, sebenarnya kurang baik, melarang merupakan sebuah sikap mendakwah atau menuduh anak untuk tidak memiliki pilihan apapun, kecuali ikut pada apa yang di larang. Dalam kondisi ini anak tidak mempunyai pilihan. Hal ini akan membuat anak semakin tertekan. Sebab, ia tidak dapat melakukan apa yang menjadi keinginannnya. keinginannya pupus dan tidak kesampaian sebab adanya http://journalfai.unisla.ac.id/index.php/JCE 
kekangan dari orang tua. Perbuatan ini juga akan berdampak negatif pada perkembangan kepribadian anak . Anak yang terlalu dilarang melakukan sesuatu akan menjadi anak yang penakut dan tidak berani bereksplorasi. Ia merasa semua yang ada disekitarnya merupakan sebuah ancaman untuk dirinya yang tidak boleh mencoba, padahal, eksplorasi sangat dibutuhkan oleh anak-anak dalam perkembangan motorik serta kemampuan dan kecerdasannya.

Peran orang tua dalam keluarga bukan hanya berperan dalam ranah kognitif tetapi yang terpenting disini adalah akhlak atau moral anak. Orang tua yang terbiasa memperlakukan anaknya dengan perkataan yang lembut dan sopan, akan terbentuk anak yang sopan dan lembut juga. Namun anak yang terbiasa dididik dengan cara yang keras, suka di atur oleh orang tua, akan terbentuk pribadi yang tidak menjadi diri sendiri, yang kemudian dinamakan pola asuh otoriter. Keluarga sebagai lembaga pendidikan tertua memiliki peran utama dalam pembentukan karakter anak, maka dibutuhkan keterampilan orang tua dalam proses pengasuhan dan pendidikan dalam keluarga. Oleh karenanya mendidik anak merupakan kerja sepanjang usia orang tua yang membutuhkan bekal pengetahuan dan pemahaman yang sangat komplek. Selain kedekatan (hubungan emosional) antar anggota keluarga, adaptabilitas (proses berbagi peran dalam keluarga), dan komunikasi antar anggota keluarga menentukan keberhasilan dalam proses pengasuhan, ternyata mendidik anak juga tidak dapat dilepaskan dari aspek pemahaman agama orang tua, karena pemahaman agama memberikan gambaran bagaimana orang tua mendefiniskan tentang anak, dunia anak hari ini, dan dunia di masa depannya. Kompleksitas persoalan kemanusiaan menuntut perlunya kontruksi pola asuh orang tua yang humanis, sehingga melahirkan anak yang memiliki komitmen kuat atau kesetiaan terhadap kemanusiaan di era digital.(Rakhmawati, 2015).

Dari permasalahan ini, peneliti menkaji lebih dalam bagaimana kepribadian anak dibentuk dari pola asuh orang tua yang otoriter, dengan menggunakan metode deskriptif kualitatif pendekatan studi kasus. 


\section{Pengertian Pola Asuh Authoritarian}

Pola asuh merupakan pola atau bentuk pengasuhan yang dilakukan oleh orang tua terhadap anak, dan termasuk dalam pengaruh mikrosistem terhadap perkembangan (Santrock. John. W, 2003). Sedangkan Orang tua adalah orang yang bertanggung jawab dalam suatu keluarga atas rumah tangga, yang dalam kehidupan sehari-hari lazim disebut "ibu dan bapak". orang tua adalah orang-orang yang bersedia berkorban demi anaknya, tanpa memperdulikan apa balasan yang akan diterimanya. Sehingga pola asuh orang tua adalah pola atau bentuk pengasuhan orang tua yang mempunyai tanggung jawab dalam memelihara anak-anakya. Pola asuh orang tua juga merupakan interaksi antara anak dan orang tua, bukan hanya pemenuhan kebutuhan fisik (seperti makan, minum dan lain-lain) dan kebutuhan psikologis (seperti rasa aman, kasih sayang dan lain-lain), tetapi juga mengajarkan norma-norma yang berlaku dimasyarakat agar anak dapat hidup selaras dengan lingkungan. Sebagai gambaran pola asuh authorian untuk anak usia 10 tahun sudah termasuk dalam kategori usia remaja awal.

Konsep diri merupakan pandangan atau penilaian remaja terhadap diri sendiri. Konsep diri yang tepat akan membantu remaja untuk mengenali dirinya dan merupakan alat kontrol bagi perilaku remaja. Apabila konsep diri remaja positif maka perilaku yang ditampilkan juga positif. Sebaliknya, apabila konsep diri remaja negatif maka perilaku yang ditampilkan akan negatif. Lingkungan keluarga, khususnya pola asuh orang tua merupakan salah satu faktor penting bagi pembentukan konsep diri remaja. Remaja akan mempersepsikan pola asuh yang diterapkan orang tua dan persepsi pola asuh tersebut akan menjadi dasar bagi remaja untuk menilai dirinya. Pengasuhan orang tua terbagi menjadi tiga pola yaitu pola authoritarian, permissive dan authoritative.(Respati et al., 2006) Setiap pengalaman menyenangkan maupun tidak menyenangkan yang dialami oleh individu akan menjadi bagian terpenting dalam kehidupannya. Penga-laman-pengalaman tersebut dapat mempe-ngaruhi cara individu dalam memandang dirinya sendiri dan dapat membentuk sebuah penilaian terhadap dirinya. Konsep diri menjadi penting karena akan mempengaruhi remaja atau siswa dalam berinteraksi dengan lingkungan. Remaja yang memiliki konsep diri positif akan tampil lebih percaya diri dalam menghadapi berbagai situasi. Sebaliknya remaja yang mengembangkan konsep diri negatif, mempunyai kesulitan dalam menerima dirinya http://journalfai.unisla.ac.id/index.php/JCE 
sendiri, sering menolak dirinya serta sulit bagi mereka untuk melakukan penyesuaian diri yang baik. Melalui konsep diri yang positif akan membantu remaja dalam menyelesaikan masalah yang dihadapi dan sebaliknya remaja yang mempunyai konsep diri yang negatif akan kesulitan dalam menyele-saikan masalahnya. Konsep diri merupakan hal pen-ting karena dengan konsep diri akan membantu individu untuk mengenali dirinya baik itu dari sisi positif dan negatif, serta apa yang boleh dan tidak boleh dilakukannya.

Dengan kata lain, konsep diri yang tepat merupakan alat kontrol positif bagi sikap dan perilaku seseorang. Salah satu faktor yang dapat membentuk konsep diri remaja adalah lingkungan keluarga, yaitu pola penga-suhan orang tua. Pola asuh merupakan cara orang tua membesarkan anak dengan memenuhi kebutuhan anak, memberi perlindungan, mendidik anak, serta mempengaruhi tingkah laku anak dalam kehidupan sehari-hari. Adapun tujuan orang tua mengasuh anaknya adalah untuk membentuk kepribadian yang matang. Dengan pengasuhan orang tua tersebut maka remaja akan belajar tentang peran-peran yang ada dalam masyarakat seperti nilai-nilai, sikap serta perilaku yang pantas dan tidak pantas, atau baik dan buruk. Segala perlakuan dari orang tua terhadap remaja sejak masa kanak-kanak, akan memberikan makna tertentu. Pemberian makna itulah yang disebut sebagai persepsi remaja terhadap pola asuh orang tua. Apabila sejak masa kanak-kanak remaja diterima, disayangi, maka remaja akan mempersepsikan bahwa orang tua sangat menghargai kehadirannya dan hal itu yang menjadi dasar bagi remaja dalam memandang dirinya. Sebaliknya jika remaja ditolak atau diabaikan, maka terbentuklah dasar penolakan bahwa dirinya tidak ber-guna. Jadi konsep diri terbentuk melalui proses belajar individu sejak masa kanak-kanak hingga dewasa. Pola asuh yang diterapkan orang tua dengan cara mendukung kegiatan remaja, menetapkan peraturan yang disertai penjelasan, memberikan kepercayaan agar remaja bertanggung jawab, menyediakan waktu untuk berkomunikasi, membe-rikan perkataan positif seperti : "kamu pasti bisa", "kamu berharga", akan membuat remaja lebih dewasa, percaya diri dan berhasil mencapai cita-citanya. Hal itu terjadi karena dukungan yang diberikan orang tua kepadanya hingga ia tidak putus asa mencoba di kesempatan lain. Dengan pengasuhan orang tua yang mendukung kegiatan remaja akan membantu remaja dalam membentuk konsep diri yang positif. 
Berbeda dengan pola asuh orang tua yang mengendalikan kegiatan remaja atau pun sebaliknya memberi kebebasan yang berlebihan, akan dipersepsi remaja bahwa orang tua kurang menghargai kebutuhannya sehingga remaja menjadi seorang yang tidak mandiri, penakut, kurang percaya diri, tidak dapat mengendalikan diri. Hal ini terjadi pada remaja usia 19 tahun, sejak umur 4 tahun diperlakukan keras oleh orang tuanya. Ia seringkali dikatakan "bodoh", dikendalikan secara ketat kegiatannya, dan diberikan hukuman fisik apabila melanggar keinginan orang tua. Akibat dari perlakuan orang tua tersebut, maka ia tidak percaya diri ketika ada di lingkungannya karena menganggap dirinya rendah, dan saat mengalami masa-lah, emosinya akan merugikan seperti memukul orang lain, menghancurkan fasilitas sekitar Remaja demikian melihat masalah sebagai sesuatu yang negatif sehingga reaksi yang ditampilkan adalah hal-hal yang negatif. Peristiwa tersebut terjadi akibat pengasuhan yang diberikan orang tua, sehingga remaja sulit menghadapi masa-lah dengan cara positif dan yang terbentuk adalah konsep diri menjadi negatif. Beberapa orang tua menganggap bahwa anak merupakan hak milik mereka, sehingga anak diperlakukan sesuai dengan keinginan orang tua. Orang tua mengatur, menguasai dan mendidik anak menurut cara yang mereka anggap benar.

Tiga pola asuh orang tua yaitu pola asuh yang bersifat otoriter/ authoritarian, demikratis dan liberal:

1. Pola asuh otoriter/ authoritarian, yaitu gaya pola asuh yang membatasi dan bersifat menghukum yang mendesak untuk mengikuti petunjuk orang tua dan untuk menghormati pekerjaan dan usaha. Orang tua yang bersifat authoritarian membuat batasan dan kendali yang tegas terhadap remaja/anak, dan hanya melakukan sedikit komunikasi verbal. pola asuh ini penuh dengan batasan dan hukuman (kekerasan) dengan cara orang tua memaksa kehendaknya, sehingga orang tua dengan pola asuh authoritarian memegang kendali penuh dalam mengontrol anak-anaknya.

2. Pola asuh liberal/permisssive, yaitu pola asuh orang tua sangat terlibat dengan remaja/anak tetapi_sedikit sekali menuntut atau mengendalikan mereka. perilaku 
permisif memanjakan berkaitan dengan ketidakcakapan sosial anak, terutama kurangnya pengendalian diri. Orang tua yang bersifat permisif memanjakan mengijinkan si anak melakukan apa yang mereka inginkan. Pola asuh ini menjadi dua: neglectful parenting dan indulgent parenting. Pola asuh yang neglectful yaitu bila orang tua sangat tidak terlibat dalam kehidupan anak (tidak peduli). Pola asuh ini menghasilkan anak-anak yang kurang memiliki kompetensi sosial terutama karena adanya kecenderungan kontrol diri yang kurang. Pola asuh yang indulgent yaitu bila orang tua sangat terlibat dalam kehidupan anak, namun hanya memberikan kontrol dan tuntutan yang sangat minim (selalu menuruti atau terlalu membebaskan) sehingga dapat mengakibatkan kompetensi sosial yang tidak adekuat karena umumnya anak kurang mampu untuk melakukan kontrol diri dan menggunakan kebebasannya tanpa rasa tanggung jawab serta memaksakan kehendaknya.

3. Pola asuh demokratis, pola asuh yang memberikan dorongan pada anak untuk mandiri namun tetap menerapkan berbagai batasan yang akan mengontrol perilaku mereka. adanya saling memberi dan saling menerima. Mendengarkan dan didengarkan. Oleh karena itu, pola asuh anak ini menggunakan penjelasan, diskusi, dan alasan dalam mendidik dan bertingkah laku, ada hukuman dan ganjaran untuk perilaku yang tidak sesuai. Selain itu hukuman yang diberikan tentunya tidak pernah keras, karena diarahkan untuk mendidik. Pengembangan kendali diri seperti ini, jelas akan membuta anak merasa puas. Anak biasanya menjadi seorang yang bisa diajak bekerja sama, mandiri, percaya diri, kreatif dan ramah. 
Pola Asuh Orang Tua dan Pengaruhnya terhadap perilaku anak berdasarkan penelitian yang dilakukan oleh Baumrind

\begin{tabular}{|c|c|c|c|}
\hline No & $\begin{array}{l}\text { Parenting } \\
\text { Styles }\end{array}$ & $\begin{array}{l}\text { Sikap atau Perilaku } \\
\text { Orang Tua }\end{array}$ & $\begin{array}{c}\text { Profil } \\
\text { Perilaku anak }\end{array}$ \\
\hline 1 & Authoritarian & $\begin{array}{l}\text { 1. Sikap "acceptance } \\
\text { rendah, namun } \\
\text { kontrolnya yang } \\
\text { tinggi. } \\
\text { 2. Suka menghukum } \\
\text { secara fisik } \\
\text { 3. Bersikap } \\
\text { mengomando } \\
\text { (mengharuskan } \\
\text { memerintah anak } \\
\text { untuk melakukan } \\
\text { sesuatu tanpa } \\
\text { kompromi) } \\
\text { 4. Bersikap } \\
\text { (keras) kaku } \\
\text { 5. Cenderung } \\
\text { emosional dan } \\
\text { bersikap menolak }\end{array}$ & $\begin{array}{l}\text { 1. Mudah tersinggung } \\
\text { 2. Penakut } \\
\text { 3. Pemurung, tidak } \\
\text { bahagia } \\
\text { 4. Mudah terpengaruh } \\
\text { 5. Mudah stres } \\
\text { 6. Tidak mempunyai } \\
\text { arah masa depan } \\
\text { yang jelas } \\
\text { 7. Tidak bersahabat } \\
\text { 8. Cenderung berontak }\end{array}$ \\
\hline 2 & Permissive & $\begin{array}{l}\text { 1. Sikap "acceptance"- } \\
\text { nya tinggi, namun } \\
\text { kontrolnya rendah } \\
\text { 2. Memberi kebebasan } \\
\text { kepada anak untuk } \\
\text { menyatakan } \\
\text { keinginannya }\end{array}$ & $\begin{array}{l}\text { 1. Bersikap impulsif } \\
\text { dan agresif. } \\
\text { 2. Suka memberontak } \\
\text { 3. Kurang memiliki rasa } \\
\text { percaya diri dan } \\
\text { pengendalian diri } \\
\text { 4. Suka mendominasi }\end{array}$ \\
\hline
\end{tabular}




\begin{tabular}{|c|c|c|c|}
\hline & & & $\begin{array}{l}\text { 5. Tidak jelas arah } \\
\text { hidupnya } \\
\text { 6. Prestasinya rendah }\end{array}$ \\
\hline 3 & Demoktaris & $\begin{array}{l}\text { 1. Sikap "acceptance" } \\
\text { dan kontrolnya } \\
\text { tinggi. } \\
\text { 2. Bersikap responsif } \\
\text { terhadap kebutuhan } \\
\text { anak } \\
\text { 3. Mendorong anak } \\
\text { untuk menyatakan } \\
\text { pendapat atau } \\
\text { pertanyaan } \\
\text { memberikan } \\
\text { penjelasan tentang } \\
\text { dampak perbuatan } \\
\text { yang baik dan yang } \\
\text { buruk }\end{array}$ & $\begin{array}{l}\text { 1. Bersikap bersahabat } \\
\text { 2. Percaya diri } \\
\text { 3. Mengendalikan diri } \\
\text { 4. Bersikap sopan } \\
\text { 5. Mau bekerja sama } \\
\text { 6. Memiliki rasa ingin } \\
\text { tahunya yang tinggi } \\
\text { 7. Mempunyai tujuan } \\
\text { hidup yang jelas } \\
\text { 8. Berorientasi pada } \\
\text { prestasi }\end{array}$ \\
\hline
\end{tabular}

(Sumber: Syamsu) (Yusuf, LN. Syamsu, 2007)

Pola asuh otoriter/ authoritarian, yaitu gaya pola asuh yang membatasi dan bersifat menghukum, yang mendesak anak untuk mengikuti petunjuk orang tua dan untuk menghormati pekerjaan dan usaha. Orang tua yang bersifat authoritarian membuat batasan dan kendali yang tegas terhadap anak, dan hanya melakukan sedikit komunikasi verbal. pola asuh ini penuh dengan batasan dan hukuman (kekerasan) dengan cara orang tua memaksa kehendaknya, sehingga orang tua dengan pola asuh authoritarian memegang kendali penuh dalam mengontrol anak-anaknya. 
Pada cara ini orang tua menentukan aturan-aturan dan batasan-batasan yang mutlak harus ditaati oleh anak. Anak harus patuh dan tunduk dan tidak ada pilihan lain yang sesuai dengan kemauan atau pendapatnya sendiri. Kalau anak tidak memenuhi tuntutan orang tua, ia akan di ancam dan dihukum. Orang tua memerintah dan memaksa tanpa kompromi. Anak lebih merasa takut kalau tidak malakukan dan bukan karena kesadaran apalagi dengan senang hati melakukan. Orang tua menentukan tanpa memperhitungkan keadaan anak, tanpa menyelami keinginan dan sifat-sifat khusus anak yang berbeda antara anak yang satu dengan anak yang lainnya. Anak harus patuh dan menurut semua peraturan dan kebijaksanaan orang tua. Sikap keras di anngap sebagai sikap yang harus dilakukan karena hanya dengan sikap demikian anak menjadi penurut.

Dengan cara otoriter, ditambah dengan sikap keras, menghukum, mengancam akan menjadikan anak "patuh" dihadapan orang tua, tetapi di belakangnya ia akan memperlihatkan reaksi-reaksi misalnya menentang atau melawan karena anak merasa 'dipaksa'. Reaksi menentang dan melawan bisa di tampilkan dalam tingkahlaku-tingkah laku yang melanggar norma-norma dan yang menimbulkan persoalan dan kesulitan baik pada dirinya maupun lingkungan rumah, sekolah dan pergaulannya. Cara otoriter memang bisa diterapkan pada permulaan usaha menanamkan disiplin, tetapi hanya bisa pada hal-hal tertentu atau ketika si anak berada dalam tahap perkembangan dini yang masih sulit menyerap pengertian-pengertian. Cara otoriter masih bisa dilakukan asal memperhatikan bahwa dengan cara tersebut anak merasa terhindar, aman dan tidak menyebabkan anak ketakutan, kecewa, menderita 
sakit karena dihukum secara fisik. Cara otoriter menimbulkan akibat hilangnya kebebasan pada anak. Inisiatif dan aktifitas-aktifitasnya menjadi "tumpul". Secara umum kepribadiannya lemah, demikian pula kepercayaan dirinya.

Menurut Diana Braumrind, mengemukakan bahwa terdapat beberapa ciri-ciri pola asuh authoritarian, antara lain: (1) Sikap "acceptance" rendah namun kontrolnya yang tinggi, (2) Suka menghukum secara fisik, (3) Bersikap mengomando (mengharuskan/ memerintah anak untuk melakukan sesuatu tanpa kompromi), (4) Bersikap kaku (keras), (5) Cenderung emosional dan bersifat menolak, (6) Disipilm keras dan hanya memberi sedikit kehangatan, dan (7) kurang mengasuh, kurang mengasihi, dan kurang simpatik.

Braumrind juga mengemukakan tentang dampak pola asuh orang terhadap perilaku anak, yaitu orang tua yang pola asuh authoritarian (otoriter), anak cenderung bersikap bermusuhan dan memberontak, anak yang orang tuanya permissive, anak cenderung berperilaku bebas (tidak kontrol), dan orang tua yang bersikap authoritative, anak cenderung terhindar dari kegelisahan, kekacauan, atau perilaku nakal.

\section{Kepribadian}

Kepribadian merupakan apa yang menentukan perilaku dalam situasi yang ditetapkan dan dalam kesadaran jiwa yang ditetapkan. Dalam bahasa populernya, istilah "kepribadian" juga berarti ciri-ciri watak seseorang individu yang kosisten, yang memberikan kepadanya suatu identitas sebagai individu yang khusus. Jika dalam bahasa sehari-hari kita anggap bahwa seseorang mempunyai kepribadian, yang kita maksudkan adalah orang tersebut 
memiliki beberapa ciri watak yang diperlihatkannya secara lahir, konsisten, dan konsekuen dalam tingkah lakunya, sehingga tampak bahwa individu tersebut memiliki identitas khusus yang berbeda dari individu lainnya (Sobur, Alex. 2003).

Menurut John J. Honigmann mengatakan bahwa kepribadian menunjukkan perbuatan-perbuatan (aksi), pikiran dan perasaan yang khusus bagi seseorang, tetapi biasanya ditunjukkan menurut keadaan. Batasan lain tentang kepribadian adalah kepribadian berasal dari kata "persona" yang berarti topeng. Dengan demikian, arti asli dari kepribadian adalah wajah palsu atau topeng dalam sandiwara yang dapat dikatakan sebagai front, wajah bagus tetapi mengandung penipuan. Kemudian, persona berarti pemain sandiwara, individu dengan kualitas tertentu dan berbeda. Oleh sebab itu, dapat diartikan personalita berarti watak seseorang yang sebenarnya dan bukan wajahnya yang palsu.

Terdapat beberapa tipe kepribadian yang dikemukakan oleh McCrae dan costa yang dikenal dengan istilah big five personality, dalam teori tersebut terdapat lima bentuk kepribadian yang mendasari perilaku individu, antara lain: (1) Neuroticism/ negative emotionality, tipe kepribadian ini bersifat kontradiktif dari hal yang menyangkut kestabilan emosi dan identik dari segala bentuk emosi yang negatif, seperti munculnya perasaan cemas, sedih tegang dan gugup. (2) Extrovert, tipe ini menyangkut hubungan dengan perilaku suatu individu khususnya dalam hal kemampuan mereka menjalin hubungan. Tipe kepribadian ini ditunjukkan dengan melalui sikapnya yang hangat, ramah, penuh kasih sayang, serta selalu menunjukkan keakraban terutama pada orang 
yang telah ia kenal. (3) Agreeableness, Tipe kepribadian ini mengidentifikasikannya dengan perilaku prososial yang mana termasuk didalamnya adalah perilaku yang selalu berorientasi pada altruisme, rendah hati dan kesabaran. (4) Conscientiousness, Tipe kepribadian ini lebih kerap diaplikasikan pada individu dalam lingkungan sosialnya terutama menyangkut sejauh mana suatu individu memiliki kebutuhan berprestasi, bertanggung jawab, dan memiliki kesungguhan hati serta kerja keras dalam mengekspresikan diri dalam suatu organisasai. Peran tipe kepribadian inipun secara umum lebih banyak berpengaruh terhadap kesehatan. (5) Openness to experience, Tipe ini mengidentifikasikan seberapa besar suatu individu memiliki ketertarikan terhadap bidang-bidang tertentu secara luas dan mendalam.

Terdapat 2 faktor utama yang dapat mempengaruhi kepribadian seseorang, yaitu: (1) hereditas (genetika), seorang pribadi terbentuk dari kromosom orang tua yang didalamnya terdapat gen yang membawa sifat-sifat fisik dan psikis seseorang yang menentukan potensi hereditasnya, (2) lingkungan (environment) keluarga, (3) kebudayaan (4) sekolah.

Sedangkan terdapat beberapa penyebab Perubahan kepribadian seorang individu antara lain: (1) Faktor fisik seperti gangguan otak, kurang gizi, mengkonsumsi obat-obat terlarang, minuman keras, dan gangguan karena sakit atau kecelakaan. (2) Faktor lingkungan seperti krisis politik, ekonomi, dan keamanan yang menyebabkan terjadinya masalah pribadi, dan masalah sosial. (3) Faktor diri sendiri seperti frustasi yang beekepanjangan, imitasi pada orang yang berkepribadian menyimpang(Yusuf, LN. Syamsu. 2005). 


\section{Kepribadian Anak dari Pola Asuh Ibu yang Authoritarian}

Memiliki anak yang pintar dan patuh merupakan dambaan setiap orang tua, terutama seorang ibu yang setiap hari selalu memegang anak mereka, tentu mempunyai keinginan yang kuat dan berusaha agar anak mereka dapat orang menjadi seorang anak yang sesuai harapan orang tua. Pembentukan watak, sifat, juga kepribadian seorang anak sangat dipengaruhi oleh lingkungan keluarga terutama ibu yang setiap harinya menjadi bagian dari kehidupan anak, hal ini karena ibulah yang setiap hari memegang dan mengasuh anak. Sehingga ibu sangat penting pengaruhnya terhadap kepribadian anak. setiap ibu pasti menginginkan anaknya untuk menjadi seorang yang patuh dan juga berhasil, dan keinginan tersebut menjadikan ibu harus ibu harus bersikap tegas terhadap anaknya, hal ini dengan alasan agar anak tidak seenaknya terhadap orang tua.

Ketegasan yang dilakukan ibu tidak jarang menjadi sikap yang ototiter, padahal sikap otoriter ibu akan sangat memberikan pengaruh yang besar dalam proses pembentukan pribadi anak. Menurut Syamsu Sikap atau perlakuan orang tua yang overdisipilin (otoriter) akan memberikan pengaruh tersendiri terhadap kepribadian anak, anak akan menjadi impulsif, nakal, bermusuhan dan agresif, bila ini terjadi secara berkelanjutan (Yusuf, LN. Syamsu. 2005). Sehingga hal ini para orang tua hendaknya berhati-hati dalam menerapkan pola asuh terhadap anaknya, terutama ibu yang setiap hari memegang anak haruslah berhati-hati dalam bersikap dan berbicara, karena apapun yang dilakukan ibu pada dasarnya itu memberikan contoh terhadap anak. sikap otoriter tidak hanya 
memberikan pengaruh terhadap kepribadian anak akan tetapi juga memberikan pengaruh terhadap perkembangan anak.Terdapat beberapa dampak perlakuan orang tua yang otoriter terhadap perkembangan anak antara lain: (1) Anak akan mudah tersinggung, dikarenakan perlakuan orang tua yang mudah menyalahkan anak, sehingga anak merasa tidak pernah benar, selalu salah dan tidak mudah diarahkan oleh orang lain selain ibunya. (2) Anak menjadi penakut, hal ini dikarenakan anak yang sering dimarahi orang tua tanpa alasan yang jelas apabila menyampaikan pendapat. (3) Anak menjadi pemurung, tidak bahagia, dikarenakan rasah bersalah teramat dalam yang disampaikan orang tuanya. (4) Mudah stress, hal ini dikarenakan pendapat yang disampaikan tidak pernah diterima orang tuanya, sering disalahkan. (5) Tidak mempunyai arah masa depan yang jelas, seorang anak yang tidak pernah mendapat penghargaan ketika melakukan kebaikan dia akan merasa semua berjalan sewajarnya, sehingga tidak ada arah tujuan yang ingin dicapai. (6) Tidak bersahabat, artinya anak lebih nyaman sendiri.

\section{Metode}

Metode penelitian ini dengan menggunakan deskriptif kualitatif pendekatan studi kasus. Yang mana dalam meneliti Kepribadian Anak Dari Pola Asuh Authoritarian Dalam Prespektif Keislaman implementasi dari metode ini orang tua menggunakan pengamatan kepada anak di dalam maupun di luar rumah. Pada saat proses belajar mengajar di rumah banyak anak yang kurang menghormati orang tua, tidak menghargai sodara, dan tidak mendengarkan arahan orang tua.Kemudian orang tua melakukan observasi dan pengamatan untuk mengetahui latar belakang anak berbuat tersebut, bagaimana 
peran orang tua terhadap pendidikan islam anak, bagaimana sikap dan perilaku siswa dalam menerapkan nilai pendidikan agama islam di rumah. Hasil dari observasi orang tua dibantu guru bahwa, banyak anak yang salah pola asuh sejak dini dan tidak sesuai dengan prespektif keislaman, karena penggunaan metode yang kurang tepat, menjadikan kurangnya penerapan nilai agama pada anak sehingga mempengaruhi perkembanagn anak. Dan orang tua mencoba melakukan pembelajaran dengan menggunakan pola asuh authoritarian yang mana malah dapat membuat anak tidak sesuai dengan pendidikan yang telah diajarkan, sehingga penanaman nilai karakter religius anak belum dapat tercapai.

\section{Pendidikan dalam perspektif islam}

Pendidikan anak yang pertama dan paling utama dalam Islam adalah pendidikan dalam keluarga yang berperspektif Islam. Pendidikan dalam keluarga yang berperspektif Islam adalah pendidikan yang didasarkan pada tuntunan agama Islam yang diterapkan dalam keluarga yang dimaksudkan untuk membentuk anak agar menjadi manusia yang beriman dan bertaqwa kepada Tuhan Yang Maha Esa, serta berakhlak mulia yang mencakup etika, moral, budi pekerti, spiritual atau pemahaman dan pengalaman nilai-nilai keagamaan dalam kehidupan sehari-hari.

Hal ini merupakan salah satu wujud amar makruf nahi munkar dalam kehidupan keluarga, yaitu dengan memberikan pendidikan kepada putra putrinya berdasarkan ajaran Islam. Anak dalam menuju kedewasaannya memerlukan bermacam-macam proses yang diperankan oleh bapak dan ibu 
dalam lingkungan keluarga. Pola atau metode pendidikan agama dalam Islam pada dasarnya mencontoh pada perilaku Nabi Muhammad SAW dalam membina keluarga dan sahabatnya. Karena segala apa yang dilakukan oleh Nabi Muhammad SAW merupakan manifestasi dari kandungan al-Qur'an. Adapun dalam pelaksanaannya, Nabi memberikan kesempatan pada para pengikutnya untuk mengembangkan cara sendiri selama cara tersebut tidak bertentangan dengan prinsip-prinsip pelaksanaan pendidikan yang dilakukan oleh Nabi SAW.(Taubah, 2016). Islam adalah ajaran agama yang memuat sejumlah aturan yang tidak sebatas pada aspek ritual semata tetapi juga mencakup aspek peradaban manusia secara keseluruhan, dengan misi utamanya sebagai rahmatal lil alamin. Islam hadir dengan menyuguhkan tata nilai yang bersifat plural dan inklusif yang merambah ke dalam semua ranah kehidupan manusia termasuk ranah pendidikan Pendidikan merupakan upaya terus menerus yang dilakukan oleh orang dewasa untuk mengarahkan, membimbing dan mengembangkan potensi dan fitrah anak yang sudah dibawa sejak lahir. Pendidikan tidak hanya dapat dilakukan setelah anak lahir bahkan jauh sebelum itu Islam memberikan rambu-rambunya yakni sejak seseorang memilih pasangan. Hal tersebut menandakan begitu pentingnya menyiapkan keturunan yang sholeh dan sholehah sebagai penerus generasi mendatang yang mampu memperjuangkan eksisnya agama Islam Berdasarkan hasil penelitian anak dalam kandungan sudah dapat dididik walaupun baru sebatas pendidikan tidak langsung ((indirect education) yakni pendidikan yang dilakukan melalui ibu yang mengandung, dengan cara ibu menjaga kesehatannya dengan nutrisi 
yang cukup, membiasakan perilaku yang karimah, menjaga emosinya dan lain sebagainya.

Orang tua dalam keluarga memiliki peran dan tanggung jawab terhadap anaknya. Setiap orang tua ingin mempunyai anak yang berkepribadian akhlak mulai atau yang saleh. Untuk mencapai keinginan tersebut, orang tua diharapkan untuk mengoptimalkan peran dan tanggung jawab sebagai orang tua terhadap anaknya. Mengasuh dan mendidik anak yang dilakukan orang tua dengan berbagai macam pola asuh seperti demokratis; otoriter; permisif; dan penelantar (acuh tak acuh). Pola asuh yang menjadi sorotan saat ini adalah pola asuh otoriter yang identik dengan tanpa kasih sayang, kekerasan, mengengkang anak, dan memaksa. Pola ini akan menjadikan batin anak tersiksa, krisis kepercayaan, potensinya tidak berkembang secara optimal, hingga mengalami trauma dan sebagainya.

Pola asuh seperti ini sangat bertentangan dengan ajaran Islam yang mengawali konsep kasih sayang dalam mendidik anak. Islam sebagai agama solutif terhadap permasalahan yang terjadi dalam keluarga tentang bagaimana mendidik anak sesuai dengan usia dan masa pertumbuhan dan perkembangan anak. Pola asuh ini telah dipraktikkan oleh Rasulullah Saw. Adapun pola asuh tersebut, yaitu: membimbing cara belajar sambil bermain pada jenjang usia 07 tahun; menanamkan sopan santun dan disiplin pada jenjang usia 7-14 tahun; dan ajaklah bertukar pikiran pada jenjang usia 14-21 tahun, dan sesudah itu lepaskan mereka untuk mandiri (Padjrin, 2016). Pelaksanaan pendidikan yang dilakukan oleh keluarga adalah pendidikan pertama yang di tempati olehanak. Orang tua merupakan pendidik pertama bagi anak-anak, karena dari orang tua 
anak mula-mulamendapatkan pendidikan. Situasi pendidikan dalam keluarga akan terwujud apabila semua pihak yangada dalam keluarga dapat menjalin kerjasama yang baik, juga berkat pergaulan dan hubungan pengaruhmempengaruhi secara timbal balik antara orang tua dan anak. Jika iklim dalam keluarga baik danmenanamkan nilai-nilai keislaman yang luhur maka tidak dapat dipungkiri tumbuh kembang anak akanberjalan dengan optimal sehingga perkembangan potensi anak juga akan berkembang dengan baik.(Sarkawi, 2019).

\section{Pembahasan}

Informan dari penelitian ini adalah DN salah satu siswa kelas SD di Surabaya, umur 10 tahun. Penelitian ini menggunakan jenis penelitian kualitatif dengan pendekatan studi kasus. Berdasarkan penelitian yang telah dilakukan, DN seorang anak yang pendiam, udah tersinggung, mudah terpengaruh, tidak percaya diri, berontak dan berani. Sedangkan orang tuanya, mudah menghukum fisik dan kaku (keras), memaksa, tegas, bersikap mengomando, dan cenderung emosional. Maka hasil penelitian menunjukkan adanya pengaruh yang sangat kuat antara pola asuh ibu yang authoritarian terhadap kepribadian anak.

Lingkungan keluarga merupakan pendidikan yang utama dan pertama, karena dalam keluarga inilah anak pertama-tama mendapatkan pendidikan dan bimbingan. Di dalam keluarga seorang anak mendapatkan pendidikan yang tiada tara nilainya. Pendidikan yang berorientasi kasih sayanglah yang diberikan oleh orang tua kepada anaknya. Pada umumnya pendidikan agama 
dalam keluarga dilakukan untuk menanamkan nilai-nilai agama, etika diantaranya budi pekerti, tingkah laku dan cara bersikap dalam kehidupan sehari-hari.

\section{Kesimpulan dan saran}

Berdasarkan dari hasil penelitian ini maka dapat disimpulkan bahwa kepribadian anak kepribadian anak dari pola asuh ibu yang authoritarian adalah anak semakin terlihat berani dengan orang tua, anak mudah berontak karena merasa dipaksa dan tidak pernah dihargai, anak mudah terpengaruh, karena melakukan sesuatu sesuai dengan intruksi orang tua. Sehingga hal ini membuat kepribadian anak kurang baik. meski disisi lain anak dapat disiplin dan belajar menghargai waktu.

\section{REFERENSI}

Adhim, Fauzil. Mohammad. (1997). Bersikap Terhadap Anak, Pengaruh Perilaku Orang Tua Terhadap Kenakalan Anak. Yogyakarta: Titian Ilahi Press

Gunarasa, D. Singgih. \& Gunarsa, D. Singgih. Yuli. (2003). Psikologi Perkembangan Anak Dan Remaja. Jakarta: Gunung Mulia

Marzuki, Chairan .A. (1998). Anak Saleh Dalam Asuhan Ibu Muslimah. Yogyakarta: Mitra Pustaka

Santrock, John. W. (2003). Adolescence Perkembangan Remaja. Jakarta: Erlangga

Yusuf SLN dan Juntika N. 2007. Teori Kepribadian. Bandung: Rosda

Yusuf, LN. Syamsu. H. Dr. (2005). Psikologi Perkembangan Anak Dan Remaja. Bandung: PT Remaja Rosdakarya.

Zurayk, Ma'ruf. (1983). Aku Dan Anakku. Bandung: Al- Bayan

Lestari, S. (2015). Pendidikan Karakter Anak dalam Keluarga. An-Nisa', 8(1), 127140.

Padjrin, P. (2016). Pola Asuh Anak dalam Perspektif Pendidikan Islam. INTELEKTUALITA, 5(1), 1. https://doi.org/10.19109/intelektualita.v5i1.720

Rakhmawati, I. (2015). Peran Keluarga dalam Pengasuhan Anak. Jurnalbimbingan Konseling Isla, 6(1), 1-18. https://doi.org/10.21043/kr.v6i1.1037

Respati, W. S., Yulianto, A., \& Widiana, N. (2006). Perbedaan Konsep Diri Antara Remaja Akhir Yang Mempersepsi Pola Asuh Orang Tua Authorian, Permissive dan Authoritative. Jurnal Psikologi, 4(2), 119-138. https://doi.org/http://digilib.esaunggul.ac.id/public/UEU-Journal-4977ibuwin.pdf. 
Sarkawi, A. (2019). MELEJITKAN POTENSI ANAK DALAM KELUARGA, DITINJAU DARI PERSPEKTIF ISLAM. Turast : Jurnal Penelitian Dan Pengabdian, 4(2), 163-176. https://doi.org/10.15548/turast.v4i2.346

Taubah, M. (2016). PENDIDIKAN ANAK DALAM KELUARGA PERSPEKTIF ISLAM. Jurnal Pendidikan Agama Islam (Journal of Islamic Education Studies), 3(1), 109. https://doi.org/10.15642/pai.2015.3.1.109-136 